Environmental Biology of Fishes, Vol. 8, No. 1, 1983, pp. 61-65.

ISSN: (Print: 0378-1919) (Electronic: 0378-1909)

DOI: $10.1007 / \mathrm{BF} 00004947$

http://www.springerlink.com/

http://www.springerlink.com/content/u8v810h3721j0675/fulltext.pdf

(C) Springer

The original publication is available at www.springerlink.com.

\title{
Escape tactics used by bluegills and fathead minnows to avoid predation by tiger muskellunge
}

\author{
Robert C. Moody, John M. Helland \& Roy A. Stein \\ Department of Zoology, The Ohio State University.
}

\section{Synopsis}

To explain why esocids prefer cylindrical, soft-rayed prey over compressed, spiny-rayed prey, we quantified behavioral interaction between tiger muskellunge $\left(\mathrm{F}_{1}\right.$ hybrid of male northern pike Esox lucius and female muskellunge E. masquinongy) and fathead minnows (Pimephales promelas) and bluegills (Lepomis macrochirus). Tiger muskellunge required four times as many strikes and longer pursuits to capture bluegills than fathead minnows. Tiger muskellunge attacked each prey species differently; fathead minnows were grasped at midbody and bluegills were attacked in the caudal area. Each prey species exhibited different escape tactics. Fathead minnows remained in open water and consistently schooled; bluegills dispersed throughout the tank and sought cover by moving to corners and edges. Due to their antipredatory behavior (dispersing, cover seeking, and remaining motionless) and morphology (deep body and spines), bluegills were less susceptible to capture by tiger muskellunge than were fathead minnows.

\section{Introduction}

Tiger muskellunge, $\mathrm{F}_{1}$ hybrid of male northern pike (Esox lucius) $\times$ female muskellunge (E. masquinongy), can be reared inexpensively and stocked into lakes and reservoirs for sport fishing (Graff 1978). In some lakes, this hybrid has exhibited superior survival, faster growth, and increased angling vulnerability, compared to its parents (Weithman \& Anderson 1977, Graff 1978, Johnson 1978).

In previous work Gillen et al. (1981) found that pellet-reared tiger muskellunge were more efficient at capturing fathead minnows (Pimephalespromelas) than bluegills (Lepomis macrochirus). In 0.05-hectare ponds, all hybrids successfully captured fathead minnows whereas few had captured any bluegills after 2 weeks. Other studies suggest that esocids select prey, choosing gizzard shad (Dorosoma cepedianum), carp (Cyprinus carpio), and minnows over centrarchids (Beyerle \& Williams 1968, Mauck \& Coble 1970, Weithman \& Anderson 1977). We designed this study to describe the behavioral interaction between tiger muskellunge and a cylindrical, soft-rayed prey - fathead minnows and a compressed, spiny-rayed species -bluegills.

\section{Methods}

Experimental protocol

We observed hybrids in a 700-liter tank $(260 \times 53 \times 60 \mathrm{~cm})$ at temperatures of $17-21^{\circ} \mathrm{C}$ and a photo-period of 14L:10D. The tank was divided into a predator-holding chamber $(50 \times 23$ 
$\mathrm{cm})$ and an experimental chamber $(210 \times 53 \mathrm{~cm})$ by an opaque divider. An opening in the middle of the divider was fitted with a remotely controlled door.

Prey were bluegills and fathead minnows of optimal size, i.e. $25 \%$ of predator length for blue-gills and $37 \%$ for minnows (Gillen et al. 1981). Number of prey at the beginning of the experiment ranged from 10 to 16 individuals and was usually 13.

Pellet-reared hybrids $(n=6)$, conditioned to live fathead minnows and bluegills for at least 2 weeks, were put in the holding chamber and starved for 48 hours before experiments. Prey were added to the experimental chamber 24 hours before each experiment. To insure the use of optimal size prey, sizes were adjusted weekly as hybrids grew from 180 to $232 \mathrm{~mm}$ total length during the experimental period.

An experiment began when the remotely controlled door was opened and a hybrid entered the experimental chamber. We measured time required to capture prey and allowed the predator 30 minutes to make a capture; the predator was then removed. Upon removal we waited 10 minutes before releasing another tiger muskellunge. We gathered data during 40 experiments for each prey species.

\section{Behavior of tiger muskellunge}

We quantified the behavior of a single predator and its interaction with a group of prey. Behavior patterns were:

Motionless - predators were stationary usually on the tank bottom and did not orient toward prey.

Recognition - the predator oriented toward an individual prey, but was usually motionless. Caudal and dorsal fins moved occasionally in preparation for attack.

Follow - after recognition, hybrids followed prey by moving slowly toward an individual or group.

Pursue - after following, hybrids chased prey at burst speed; often, one or more attempts to capture prey occurred. Pursuit began at initiation of burst speed and ended upon either capture or cessation of burst speed.

Strike - most pursuits terminated when the predator attacked, i.e., attempted to make a capture. Strikes were fast-start acceleration lunges directed at an individual (as described by Webb \& Skadsen 1980). Not all strikes involved prey contact. For successful strikes, we recorded the area on the body of the prey that was grasped initially.

Predator distribution - movements of the predator were quantified by recording which of eight sections $(25 \times 53 \mathrm{~cm}$ each $)$ of the tank the predator occupied and locations of strikes and captures. Prey behavior - we described escape responses of prey by noting when prey swam faster than normally away from a predator and when prey sought cover along tank edges and corners.

In quantifying predator behavior, we counted the number of recognitions and strikes; time spent by predators in behaviors such as recognition, follow, pursue, and motionless was measured with a stopwatch.

\section{Results}

Behavior of tiger muskellunge 
Predator sequences usually consisted of prey recognition, follow, pursue, and strike, ending in either a successful strike or the predator remaining motionless. Not all behaviors were always observed, e.g., pursuits without strikes, nor did they always occur in this prescribed sequence, e.g., motionless sometimes occurred before recognition.

Selection of an individual by hybrids for pursuit differed slightly between minnows and bluegills. With minnows, tiger muskellunge mainly selected the nearest prey that were usually in schools. In contrast, bluegills that were attacked were usually solitary.

Predators followed bluegills more frequently than minnows (Table 1; Mann-Whitney Utest, $\mathrm{p}<0.01$ ). Follows, which led to pursuit for both prey species, often were marked by a hesitation of movement (1-5 seconds) just before pursuit. All minnow follows resulted in pursuit whereas only about $50 \%$ of the bluegill follows progressed to pursuit, i.e., follows often ended without a strike.

Table 1. Behavior of tiger muskellunge preying on optimal sized bluegills and fathead minnows. Medians and $95 \%$ confidence intervals calculated by use of Walsh averages (Hollander \& Wolfe 1973). Significance levels were based on the Mann-Whitney U-test.

\begin{tabular}{|c|c|c|c|c|c|c|c|}
\hline \multirow{3}{*}{$\begin{array}{l}\text { Behavioral category } \\
\text { of predator }\end{array}$} & \multicolumn{6}{|c|}{ Prey species } & \multirow{3}{*}{$\begin{array}{l}\text { Significance } \\
\text { level } \\
\text { (p) }\end{array}$} \\
\hline & \multicolumn{3}{|c|}{ Fathead minnow } & \multicolumn{3}{|c|}{ Bluegill } & \\
\hline & $\mathrm{n}$ & Median & $\begin{array}{l}95 \% \text { confidence } \\
\text { interval }\end{array}$ & $\mathrm{n}$ & Median & $\begin{array}{l}95 \% \text { confidence } \\
\text { interval }\end{array}$ & \\
\hline Number of follows ${ }^{a}$ & 18 & 0.5 & $0.5-1.0$ & 46 & 0.5 & $0.0-6.0$ & 0.01 \\
\hline Pursuit time (s) per capture & 64 & 1.0 & $0.8-1.5$ & 80 & 3.0 & $1.8-4.8$ & 0.001 \\
\hline Number of strikes per capture & 25 & 2.0 & $1.5-2.5$ & 21 & 7.5 & $5-10$ & 0.001 \\
\hline Time (s) spent motionless & 50 & 86 & $59-123$ & 87 & 129 & $86-189$ & 0.08 \\
\hline $\begin{array}{l}\text { Total time required }(\mathrm{s}) \text { for } \\
\text { capture after predator release }\end{array}$ & 28 & 185 & $90-300$ & 14 & 390 & $90-810$ & 0.34 \\
\hline
\end{tabular}

${ }^{a}$ For many captures, tiger muskellunge did not follow; the value of 0.5 reflects the incorporation of these zeros into the calculation.

Pursuit times were longer for bluegills than minnows (Table 1; Mann-Whitney U-test, p < 0.001). Pursuits for both minnows and bluegills usually ended in strikes. Tiger muskellunge required nearly four times as many strikes to capture a bluegill than a minnow (Table 1; MannWhitney U-test, $\mathrm{p}<0.001)$. Time spent motionless for those trials that ended in capture was longer for bluegills than for minnows (Table 1; Mann-Whitney U-test, $\mathrm{p}<0.08$ ). When predation sequences that did not end in capture were included, these differences became much larger (Mann-Whitney U-test, $\mathrm{p}<0.001$ ), suggesting that predators were less apt to attack bluegills than minnows.

Tiger muskelunge successfully captured fathead minnows in $80 \%$ ( $n=40$ trials each) of their attempts but were only $52 \%$ successful for bluegills. We found no difference in total times to capture between minnows and bluegills (Mann-Whitney U-test, $\mathrm{p}=0.34$ ), but the 95\% confidence intervals were nearly three times as large for bluegills as minnows (Table 1). Long times to capture (i.e., from the time a hybrid was released until a prey was captured) for minnows were due mainly to their higher incidence of escape, which was two times (23\% versus $9 \%)$ that of bluegills. After minnows escaped, tiger muskellunge often pursued them again, thus increasing overall time to capture. 
Predators attacked minnows at midbody and bluegills in the caudal area:

\begin{tabular}{lcccc}
\hline Prey & $\mathrm{n}$ & Head & $\begin{array}{c}\text { Mid- } \\
\text { body }\end{array}$ & $\begin{array}{l}\text { Caudal } \\
\text { area }\end{array}$ \\
\hline Minnow & 35 & $14 \%$ & $49 \%$ & $37 \%$ \\
Bluegill & 16 & $31 \%$ & $6 \%$ & $63 \%$ \\
\hline
\end{tabular}

\section{Prey behavior and distribution}

Before predator introduction, fathead minnows were grouped into schools about $10 \times 10$ $\times 10 \mathrm{~cm}$ that were relatively inactive. When the predator was introduced, these schools moved within $20 \mathrm{~cm}$ of the tank bottom. Most of these schools were also closely associated with tank corners; only five $(7 \%)$ occurred in open water away from tank walls and bottom.

Before predator release, bluegills were loosely grouped within a volume of about $30 \times 15$ $\times 15 \mathrm{~cm}$. At predator release, bluegills often dispersed with small groups or individuals moving to the surface or bottom within tank corners. In an otherwise cover-free environment, we observed individual bluegill attempting to reduce their susceptibility by orienting its body parallel to a tank wall and remaining motionless $0-1 \mathrm{~cm}$ away from the wall. Usually this behavior occurred in the upper level, frequently at the surface.

After a capture or after 30 minutes, final minnow schools were about $10 \times 25 \times 25 \mathrm{~cm}$ and bluegills were widely dispersed throughout the tank. Both prey species were usually captured within $20 \mathrm{~cm}$ of the bottom. However, bluegill captures were more evenly distributed throughout all three levels than were minnow captures (Table 2).

Patterns of escape behavior differed between prey species. When a predator approached within about $15 \mathrm{~cm}$ a minnow school would swim rapidly, usually individuals in single file, away from the predator. Often, the school moved to the tank bottom, sometimes passing, over or along predators' sides, forming a more typical school once past the predator. Bluegill escape behavior began when a predator approached within about $25 \mathrm{~cm}$. Typically, single individuals (but at times two or three blue-gills) quickly swam away (much more rapidly than minnows). The resulting movement was both horizontal, averaging about $75 \mathrm{~cm}$, and vertical, generally from surface to bottom.

\section{Discussion}

In five independent experiments $(\mathrm{n}=$ four 0.05 -hectare ponds with and without vegetation per experiment) using tiger muskellunge, we have found that these predators cannot capture bluegills (Gillen et al. 1981, Stein et al. 1981, CM. Tomcko, Ohio Cooperative Fishery Research Unit, The Ohio State University, personal communication). Yet, in these same experiments, hybrids preyed successfully on fathead minnows. Similar results have been obtained by other workers (Beyerle \& Williams 1968, Weithman \& Anderson 1977). To the extent that the behavior patterns used by bluegills and fathead minnows to avoid tiger muskellunge in our laboratory tank (with vertical walls and no cover) reflects their escape tactics in the field, we have partially explained their differential susceptibility. Bluegills require more 
follows, longer pursuit times, and more strikes per capture than fathead minnows, and as such, are less vulnerable to predation.

Table 2. Percent of strikes and captures in three depths by tiger muskellunge preying on optimal sized bluegills and minnows. Open water was any area more than $20 \mathrm{~cm}$ from tank walls or bottom.

\begin{tabular}{|c|c|c|c|c|c|c|c|c|}
\hline & \multicolumn{4}{|c|}{ Fathead minnow } & \multicolumn{4}{|c|}{ Bluegill } \\
\hline & $\mathrm{n}$ & $\begin{array}{l}\text { Upper } \\
20 \mathrm{~cm}\end{array}$ & $\begin{array}{l}\text { Middle } \\
20 \mathrm{~cm}\end{array}$ & $\begin{array}{l}\text { Lower } \\
20 \mathrm{~cm}\end{array}$ & $\mathrm{n}$ & $\begin{array}{l}\text { Upper } \\
20 \mathrm{~cm}\end{array}$ & $\begin{array}{l}\text { Middle } \\
20 \mathrm{~cm}\end{array}$ & $\begin{array}{l}\text { Lower } \\
20 \mathrm{~cm}\end{array}$ \\
\hline Total strikes & 68 & $0 \%$ & $6 \%$ & $94 \%$ & 162 & $17 \%$ & $33 \%$ & $50 \%$ \\
\hline Open-water strikes & 20 & $0 \%$ & $15 \%$ & $85 \%$ & 73 & $4 \%$ & $40 \%$ & $56 \%$ \\
\hline Total captures & 32 & $0 \%$ & $9 \%$ & $91 \%$ & 21 & $24 \%$ & $28 \%$ & $48 \%$ \\
\hline
\end{tabular}

These antipredatory behavioral patterns may well be related to differences in morphology between bluegills and fathead minnows. Given their laterally compressed body and fin placement, bluegills are more maneuverable than are the more fusiform fathead minnows (Alexander 1967, Keast \& Webb 1966). Apparently, both species have equivalent fast-start capabilities (Webb 1978); thus, maneuverability probably most contributes to long pursuit times and reduced capture success (also see Howland 1974). Conceivably, bluegill spines also contribute to increasing the number of strikes required for capture. As suggested by Webb \& Skadsen (1980), the midbody of the prey is most easily grasped by the predator because this region moves least during prey escape. Consistent with their results, we also found that minnows were most often grasped at midbody. In contrast, bluegills were usually caught by the caudal area suggesting that spines at the midbody may redirect the attack of a predator thus reducing capture success.

Through their escape tactics and distribution in the tanks, bluegills eluded capture by hybrids more effectively than fathead minnows. Antipredatory behavior and morphology of these two prey species appear to combine to account for their differential susceptibility to tiger muskellunge.

\section{Acknowledgements}

We thank R.F. Carline, R. S. Hayward, E.A. Marschall, S. Klosiewski, E. Rankin, and J. F. Savino for their constructive reviews of this manuscript. This research was supported in part by funds from the Federal Aid in Fish Restoration Act under Dingell-Johnson Project F-57-R.

\section{References cited}

Alexander, R. McN. 1967. Functional design in fishes. Hutchinson, London. 160 pp.

Beyerle, G. B. \& J. E. Williams. 1968. Some observations of food selectivity by northern pike in aquaria. Trans. Amer. Fish. Soc. 97: 28-31.

Gillen, A. L., R. A. Stein \& R. F. Carline. 1981. Predation by pellet-reared tiger muskellunge on bluegills and minnows in experimental systems. Trans. Amer. Fish. Soc. 110: 199-211.

Graff, D. R. 1978. Intensive culture of esocids: the current state of the art. Amer. Fish. Soc. Spec. Publ. 11: $195-201$. Hollander, M. \& D. A. Wolfe. 1973. Nonparametric statistical methods. John Wiley and Sons, New York. 503 pp. 
Howland, H. C. 1974. Optimal strategies for predator avoidance: the relative importance of speed and maneuverability. J. Theor. Biol. 47: 333-350.

Johnson, L. 1978. Evaluation of esocid stocking program in Wisconsin. Amer. Fish. Soc. Spec. Publ. 11: 278-307.

Keast, A. \& D. Webb. 1966. Mouth and body form relative to feeding ecology in the fish fauna of a small lake, Lake Opinicon, Ontario. J. Fish. Res. Board Can. 23: 1845-1874.

Mauck, W. L. \& D. W. Coble. 1970. Vulnerability of some fishes to northern pike (Esox lucius) predation. J. Fish. Res. Board Can. 28: 957-969.

Stein, R. A., R. F. Carline \& R. S. Hayward. 1981. Evaluation of fish management techniques: evaluation of stocking tiger muskies in Ohio lakes. Ohio Federal Aid Project F-57-R. Ohio Division of Wildlife, Columbus, Ohio. 41 pp.

Weithman, A. S. \& R. O. Anderson. 1977. Survival, growth, and prey of Esocidae in experimental systems. Trans. Amer. Fish. Soc. 106: 424-430.

Webb, P. W. 1978. Fast-start performance and body form in seven species of teleost fish. J. Exp. Biol. 74: 211-226.

Webb, P. \& J. M. Skadsen. 1980. Strike tactics of Esox. Can. J. Zool. 58: 1462-1469. 